\title{
Contouren van een christelijke seksuele ethiek
}

\author{
A.L.Th. de Bruijne
}

This essay outlines the contours for Christian sexual ethics in the context of late modern concept of 'sexuality' and the state of affairs in current Western culture. On theological-anthropological grounds the essay distinguishes between sex and eros and proposes a definition of sexuality; basic biblical-theological themes point to a Christological-eschatological approach, including a plea for ascetism and sexual selfdiscipline. The essay then discusses a number of practical-ethical topics, including sexuality in marriage, cohabitation, masturbation, transgenderism and homosexuality.

Sinds de seksuele revolutie staat seksualiteit hoog op de agenda van de christelijke ethiek. ${ }^{1}$ Deze revolutie vormde aanvankelijk een opstand van jongere generaties tegen de verburgerlijkte westerse cultuur. Al vrij gauw namen anderen de nieuwe seksuele moraal over. Daarbij speelden de media een doorslaggevende rol. In de jaren '70 en ' 80 propageerden deze een vrijere seksuele moraal en vertoonden zij frequent seksueel expliciete programma's. Bij het ouder worden van deze protestgeneratie werd de nieuwe moraal vanzelfsprekend.

Dat zette druk op de christelijke seksuele moraal. Burgerlijke waarden waren vaak ook christelijke waarden. Vanouds door de meerderheid van de bevolking gedragen, raakten ze nu gemarginaliseerd. Dat bleek rond thema's als samenwonen, seksuele contacten voor en buiten het huwelijk, overspel, pornografie, publieke erotiek, voorbehoedmiddelen, homoseksualiteit, zelfbevrediging, en zelfs pleidooien pro incest en pedoseksualiteit.

Aanvankelijk voerden traditionele christenen een cultuurstrijd tegen de

1 Paul Schnabel, 'Het verlies van de seksuele onschuld', in: Gert Hekma e.a. (rred.), Het verlies van de onschuld. Seksualiteit in Nederland, Amsterdam 1990, 11-50; Evert Ketting, 'De seksuele revolutie van jongeren', in: Hekma, Verlies, 69-84; Gabriele Kuby, Die Globale Sexuelle Revolution. Zerstörung der Freiheit im Namen der Freiheit, Kisslegg 2016; Heleen Zorgdrager, 'Tussen Hooglied en \#MeToo. Een publiek-theologische bijdrage aan het debat over seksualiteit' (Diësrede PThU 2019), https://www.pthu.nl/Over-PThU/ Organisatie/Medewerkers/h.e.zorgdrager/downloads/gesproken-versie-tussen-hooglied-enmetoo-zorgdrager.pdf - geraadpleegd 04-09-2019). 
nieuwe seksuele moraal. ${ }^{2}$ Toch beïnvloedde deze hen ook, alleen al doordat seksualiteit bespreekbaar werd. Nieuwere generaties christenen namen bovendien aspecten van de seksuele revolutie over, vaak door de invloed van televisie en internet. Beelden, opvattingen en praktijken via de media bleken invloedrijker dan opvoeding, onderwijs en catechese. Voorhuwelijkse seksuele omgang is inmiddels ook praktijk voor veel orthodox-christelijke jongeren. Incidentele seksuele contacten zijn niet meer ondenkbaar. Opvattingen over homoseksualiteit verschuiven snel. En, hoewel niet zonder gewetensmoeite, ontkomen velen niet aan regelmatige consumptie van internetporno. De seksuele revolutie herhaalt zich in christelijke kring. ${ }^{3}$

In dit artikel schets ik de contouren van een christelijke seksuele ethiek. Eerst analyseer ik enkele methodische en inhoudelijke contextuele uitdagingen. Vervolgens ontwikkel ik een theologisch-antropologische visie op seksualiteit. Daarna presenteer ik bijbels-theologische lijnen als ethisch kader. Ten slotte vraag ik aandacht voor enkele praktisch-ethische uitdagingen.

\section{Contextuele complicaties en uitdagingen voor een seksuele ethiek}

\section{a. Seksuele ethiek?}

Wie de contouren wil schetsen van een christelijke seksuele ethiek, stuit op een voorvraag. Past het wel om een 'seksuele ethiek' te ontwikkelen? Voor veel christenethici is dat vanzelfsprekend ${ }^{4}$ maar belangrijke vakgenoten ver-

2 Ad de Bruijne, 'Seksualiteit en cultuurstrijd: een theologisch voorstel tot dialoog', Religie \& Samenleving 11 (2016), 2,271-278; Peter Kreeft, How to Win the Culture War. A Christian Battle Plan for a Society in Crisis, Downers Grove 2002.

3 O.A. Bakker e.a. 'Seksuele attitudes en seksuele beleving van christenen met orthodoxe geloofsovertuigingen', Tijdschrift voor Seksuologie 39 (2015), 2, 54-62. Aukelien van Abbema, 'Seks voor het huwelijk \& christelijke studenten. Een onderzoek naar definitie, moraal en gedrag rond seksualiteit', Radix 33 (2007), 1, 46-67; Barna Group, Majority of Americans Now Believe in Cohabitation', Research Releases in Family \& Kids (24-06-2016), https://www.barna.org/research/family-kids/research-release/majority-of-americans-nowbelieve-in-cohabitation\#.V6n1qqbr270 - geraadpleegd 09-08-2016; Evangelische Omroep, '40\% christelijke studenten heeft seks voor huwelijk, (2007) https://www.eo.nl/geloven/ nieuws/item/40-christelijke-jongeren-heeft-seks-voor-het-huwelijk/ - geraadpleegd 07-082016; Rien van den Berg, 'Pornostilte', Nederlands Dagblad 25-02-2013; Maarten K. Boersema, Tussen droom en daad. Een empirisch onderzoek naar de beelden van seksualiteit bij jongeren en de invloed van deze beelden op hun seksuele moraal en praktijk (Master thesis Theologische Universiteit), Kampen 2012, 48v.

4 Bijvoorbeeld J. Douma, Seksualiteit en huwelijk, Kampen 1993. 
werpen deze categorie. ${ }^{5}$ Wannenwetsch betoogt dat 'seksuele ethiek' een loot is aan de stam van de moderne verzelfstandiging van levensterreinen. Deze claimen een eigen normativiteit en raken los van de betekenis gevende kaders die de Schepper stelde. ${ }^{6}$ Wannenwetsch doelt op de klassieke lutherse standen die hij meer dynamisch opvat als 'levensvormen'. Seksualiteit is niet geschapen als zelfstandig fenomeen maar vormt deel van de levensvorm 'huwelijk'. Morele vragen rond seksualiteit zijn daarom morele vragen over het huwelijk. Wie inzet met 'seksuele ethiek', sorteert direct scheef voor en dient bewust of onbewust een revisionistische agenda die seksualiteit en huwelijk ontkoppelt.

Op het eerste gezicht lijkt Wannenwetsch' analyse eenzijdig. Meerdere christenethici schreven een 'seksuele ethiek' die de traditionele benadering trouw bleef. Grenz bijvoorbeeld beschouwt niet het huwelijk maar seksualiteit als primaire antropologische werkelijkheid. Seksualiteit is de 'drive to bonding' en markeert dat de mens aangelegd is op intieme verbondenheid met de ander. Het huwelijk ziet hij als eerste vormgeving van deze 'drive', die daarbij nog de vorm aanneemt van geslachtelijke omgang. Op weg naar de eschatologische bestemming van mens-zijn maakt deze echter plaats voor de verbondenheid van de nieuwe mensheid met en in Christus. Daarbij verdwijnen huwelijk en geslachtsgemeenschap. ${ }^{7}$ Wannenwetsch verwacht juist een blijvende plaats voor het huwelijk in Gods toekomst. Ondanks dit verschil reserveren beiden geslachtelijke omgang voor het huwelijk van man en vrouw.

Toch verdient Wannenwetsch' reserve bij 'seksuele ethiek' overweging. Een recent overzichtswerk over theologie, seksualiteit en gender stelt vragen bij het concept 'seksualiteit' zelf. Hoezeer vandaag ook ingeburgerd, tot aan de negentiende eeuw was dat onbekend. Het is een laatmodern construct, opgekomen in het kielzog van de termen 'homoseksualiteit' en 'heteroseksualiteit'. ${ }^{8}$ De latere seksuele revolutie staat niet los van de nieuwe manier van

5 Bijvoorbeeld Stanley Hauerwas (Sanctify them in the Truth. Holiness Exemplified, Edinburgh 1998,105; A Better Hope. Resources for a Church Confronting Capitalism, Democracy and Postmodernity, Grand Rapids 2000, 49.

6 Bernd Wannenwetsch, "Wovon handelt die "materiale Ethik"? Oder: Warum die Ethik der elementaren Lebensformen ("Stände") einer "Bereichsethik" vorzuziehen ist. Oswald Bayer zum sechzigsten Geburtstag,, in: Andres Fritschze, Manfred Kwiran (red.), Kirche(n) und Gesellschaft, München 2000, 95-136, 102-105.115.

7 Stanley Grenz, Sexual Ethics. An Evangelical Perspective (2e druk), Louisville 1997, 23-35. $191,219 \mathrm{v}$.

8 Adrian Thatcher, 'Introduction', in: Adrian Thatcher (red.), The Oxford Handbook of Theology, Sexuality, and Gender, Oxford 2015, 3-17, 5vv; Elizabeth Stuart, 'The Theological Study of Sexuality', in; Thatcher, Handbook, 18-31, 18v. 
kijken naar mensen en hun relaties die meekwam met dit concept 'seksualiteit'. Bovendien impliceert dit concept een hermeneutische complicatie. Wie een bijbelse visie op 'seksualiteit' wil ontwikkelen, hanteert een concept dat de Bijbel niet kent en zoekt een antropologische werkelijkheid die in de Bijbel niet op dezelfde manier bestaat als vandaag. Zomaar raken bijbelinhouden daardoor te gemakkelijk verbonden aan wat wij 'seksualiteit' noemen. Wij zullen ons een verantwoord beeld moeten vormen van de kaders waarin de Bijbel spreekt over fenomenen die wij vandaag scharen onder 'seksualiteit'. Zo vatten wij het 'begeren' uit het tiende gebod gemakkelijk op als seksuele lust. In het gebod staat de vrouw van de naaste echter op één lijn met diens bezit. Misschien vormt niet het seksuele de spits maar respect voor de rechten van de (mannelijke) naaste. Kortsluiting treedt ook gemakkelijk op rond de vriendschap van David en Jonathan. Als liefde tussen mannen wonderlijker heet dan voor een vrouw, ontstaan vandaag automatisch 'seksuele' connotaties, die binnen het Oude Testament niet passen. Omgekeerd kan die bijbelse vriendschap dimensies hebben omvat, die wij vandaag 'seksueel' noemen maar die destijds los stonden van geslachtelijke omgang. ${ }^{9}$ Te denken valt aan wederzijdse liefde, aantrekking en verlangen, oog voor schoonheid, lichamelijkheid en zelfs intieme nabijheid. Nog altijd bewijst de context van familierelaties dat zulke aspecten niet per definitie 'seksueel' gekleurd zijn.

Tegen deze achtergrond verdient het overweging om helemaal afstand te nemen van de moderne concepten 'seksualiteit' en 'seksuele ethiek'. Dit vergt echter al onder christenen een vooralsnog onwaarschijnlijke omslag in denken en compliceert bovendien communicatie met anderen. Realistischer is een eigen afbakening van 'seksualiteit' en 'seksuele ethiek' te zoeken. Daartoe analyseer ik eerst nader wat 'seksualiteit' in de laatmoderne context inhoudt.

\section{b. Ontwikkelingen in de laatmoderne seksualiteit}

Twee fundamentele verschuivingen bepalen het karakter van laatmoderne 'seksualiteit'. In de eerste plaats kleurt dit negentiende-eeuwse construct steeds meer dimensies van mens-zijn. Het gaat namelijk niet meer om een publieke werkelijkheid verbonden aan huwelijk en voortplanting, maar om een geprivatiseerd kenmerk van individuen. ${ }^{10}$ Ieder bezit een eigen 'seksuali-

9 Susan Ackerman (red.), When Heroes Love. The Ambiguity of Eros in the Stories of Gilgamesh and David, New York 2005.

10 Stanley Hauerwas e.a., The Hauerwas Reader, Durham 2001, 484; Dale S. Kuehne, Sex and the iWorld. Rethinking Relationship beyond an Age of Individualism, Grand Rapids 2009, 61-99; Jenell Williams Paris, The End of Sexual Identity. Why Sex Is Too Important to Define Who We Are, Downers Grove 2011. 
teit', die geldt als bepalend voor ieders identiteit. Omdat je een identiteitskenmerk overal meeneemt, kleurt het steeds meer dimensies van het mens-zijn. Iemands seksualiteit is zelfs de verborgen drijfkracht achter willen en handelen genoemd. ${ }^{11}$ Zo raakten het lichamelijke, gevoelens, begeerten en intermenselijke contacten geseksualiseerd. Sommigen noemen alle intermenselijke interactie 'seksueel' geladen. Tegen deze achtergrond staan fenomenen als 'one night stand' en 'friends with benefits'. Ook bij eenmalige ontmoetingen en gewone vriendschappen kan het bed gedeeld worden. ${ }^{12}$

Ten tweede bezit dit fenomeen 'seksualiteit' geen voorgegeven betekenis meer. Betekenis ontbreekt of wordt toegekend door mensen zelf. Dit hangt samen met de opkomst van anticonceptie, waardoor de eens vanzelfsprekende verbinding tussen geslachtsverkeer en voortplanting verdween. ${ }^{13}$

Deze fundamentele verschuivingen bewerken verdergaande ontwikkelingen. Velen ervaren 'seksualiteit' als moreel neutraal. In een geprivatiseerde liberale ethiek bepalen individuele voorkeuren het handelen, slechts begrensd door beginselen als 'respect voor autonomie' en 'geen schade'. ${ }^{14}$ Alles mag mits uit vrije wil en zonder schade voor een ander. Men erkent geen algemene morele normen die de geprivatiseerde omgang met seksualiteit richten en begrenzen. Intussen groeit onder de oppervlakte juist een nieuwe consensus, namelijk van seksualiteit als lichamelijke basisbehoefte of genotmiddel. Seks is onontbeerlijk voor geluk. Dat leidt tot een rechtendiscours rond seksualiteit. Elk individu heeft recht op de vervulling van deze basisbehoeften en op dit genotmiddel. Iemand dit recht onthouden is discriminatie. ${ }^{15}$

Naast deze libertinistische nadruk op individuele behoefte en genot ont-

11 Paul Moyaert, 'Met Freud opnieuw nadenken over seksualiteit', in: Mark Kinet, Koen Baten (red.), Psychoanalyse als seksuologie. Libido van gesel tot gezel, Antwerpen 2015, 13-36.

12 M.A. Bisson e.a., 'Negotiating a Friendship with Benefits Relationship', Archives of Sexual Behavior 38 (2007), 66-73.

13 Schnabel, Verlies.

14 Gerrit Manenschijn, 'Sexual Morality, Worldview, and Social Change', in: Bert Musschenga (red.), Does Religion Matter Morally, Kampen 1995, 59-88, 80-85.

15 Igor Primoratz, Ethics and Sex, New York 1999, 46; Alan H. Goldman, 'Plain Sex', in: Philosophy and Public Affairs 6 (1977), 3, 267-287; Hanneke de Graaf e.a., Seks onder je $25^{e}$. Seksuele gezondheid van jongeren in Nederland anno 2017, Delft 2017, 77, 94, 206, 216; Marianne Cense e.a., Laveren tussen autonomie en loyaliteit. Seksuele ontwikkeling en beleving van allochtone jongeren (Rutgers WPF), Utrecht 2012, 56; Margaret A. Farley, Just Love. A Framework for Christian Sexual Ethics. New York 2006 (m.n. hoofdstuk 5); https:// www.rutgers.nl/wat-wij-doen (geraadpleegd 20-06-2019). 
staat een romantische variant van seksualiteit. ${ }^{16}$ Daarbij dient seksualiteit de individuele zelfverwerkelijking. Alleen in een seksuele partnerrelatie wordt een mens zichzelf. Soms versterkt dit een ideaal van levenslange monogamie, soms ook seriële monogamie. Recentelijk werd deze romantische variant sterker. Dat blijkt uit pleidooien tot matiging van seksuele vrijheid en tot seksuele trouw. ${ }^{17}$

Seksualiteit als basisbehoefte of genotmiddel valt vervolgens ten prooi aan de markt. ${ }^{18}$ Seks wordt geëxploiteerd tot winstgevend product dat wordt afgenomen en geconsumeerd. In verschijnselen als bedrijfsmatige prostitutie, vrouwenhandel, internetporno en sexting sneuvelt daarbij het 'geen-schadebeginsel'. Een marktmechanisme kleurt ook de individuele omgang met seksualiteit. Individuen zetten hun seksualiteit in voor onderlinge competitie. Mode en uiterlijke presentatie communiceren seksuele boodschappen. Kleding die vrouwelijke seksualiteit verhult (boerka) roept meer verontwaardiging op dan kleding die deze exploiteert. Commercialisering van seksualiteit blijkt ook in reclames, muziekclips, popconcerten, en mediaprogramma's over thema's die zelf niets met seksualiteit te maken hebben.

Een belangrijke laatmoderne ontwikkeling is het 'seksueel moratorium'. ${ }^{19}$ Jongeren worden vroeger geslachtsrijp en later volwassen. Daardoor groeien het begin van seksueel experimenteren en het begin van vaste relaties uiteen.

16 Bernd Wannenwetsch, Die Freiheit der Ehe. Das Zusammenleben von Frau und Mann in der Wahrnehmung evangelischer Ethik, Neukirchen 1993, 154-163; Manenschijn, Sexual, 85v; Eva Illouz, Der Konsum der Romantik: Liebe und die kulturellen Widersprüche des Kapitalismus, Frankfurt am Main 2011.

17 Roger Scruton, Sexual Desire. A Moral Philosophy of the Erotic, New York 1986; Alain De Botton e.a., Meer denken over seks: hoe doe je dat? Utrecht 2012; Janita Naaijer, 'Worden we preutser', De Volkskrant 17-03-2016 (http://www.volkskrant.nl/opinie/rondvraagworden-we-preutser a4265231 - geraadpleegd 08-07-2016); Koen Raes, 'Seksuele bevrijding is ook een ethisch project. Over de instrumentalisering van de erotiek', in: Suzette Haakma (red.), Minnen met de zinnen. Opvattingen over erotiek in verschillende culturen, Utrecht 1999, 11-40; Bram Bakker, Over seks gesproken, Amsterdam 2012, 91.

18 Hauerwas, Hope, 50.

19 Adrian Thatcher, Living Together and Christian Ethics, Cambridge 2002, 28-33; Ron van der Vliet, 'De opkomst van het seksuele moratorium', in: Hekma, Verlies, 51-68; Ketting, Revolutie, 79vv; Cas Wouters, De jeugd van tegenwoordig. Emancipatie van liefde en lust sinds 1880, Amsterdam 2012; H. de Graaf e.a., Seks in de groei, update anno 2009. Recente wetenschappelijke inzichten in de seksuele ontwikkeling van kinderen en jeugdigen, Utrecht 2009. 
Blijkens onderzoek en alledaagse ervaring gaat dit alles christenen niet voorbij. ${ }^{20}$ Ook christelijke hulpverleners noemen seks een behoefte, adviseren om ervan te genieten ${ }^{21}$ of romantiseren seks tot één van de liefdestalen in een exclusieve tweerelatie. ${ }^{22}$ Sommigen noemen seksualiteit hoogdravend een heilig instrument van wederzijdse vervulling. ${ }^{23}$ Internetporno en pornoverslaving blijken wijdverbreid. Dat geldt in mindere mate ook voor seksuele dates en seksuele zelfpresentatie. Ook christenen aarzelen over de betekenis van seksualiteit, en zien deze vaak als behoefte en genotmiddel. ${ }^{24}$ Christelijke jongeren die vasthouden aan de koppeling tussen seksuele praxis en huwelijksverbond lijken te moeten kiezen tussen een te vroege huwelijkssluiting of een te lange verkeringstijd. Tegen die achtergrond komen ook relaties tussen christelijke jongeren vaak in fasen tot stand, waarbij seksualiteit al relatief vroeg aan de orde is. Wie vandaag de contouren schetst van een christelijke seksuele ethiek kan niet volstaan met een tijdloze herhaling van bijbelse uitgangspunten, maar moet inspelen op deze actuele context.

\section{Theologisch-antropologische afbakening van seksualiteit}

Voor een verantwoorde omschrijving van seksualiteit bouw ik voort op de theologische antropologie van de ethici De Knijff en Burggraeve. In navolging van anderen (Lewis, Nygren) ontwikkelde De Knijff een typologie van de lief-

20 Marco Derks, 'Sexual and Religious Regimes of the Self in Dutch Discourses about Homosexuality. A Queer Theological Analysis and Alternative', International Journal of Public Theology 12 (2018), 3/4, 353-378; Marco Derks e.a., 'Under the Spell of the Ring. The Role of Marriage in Moral Debates among Orthodox Reformed Christians in the Netherlands', Theology \& Sexuality 20 (2014), 1, 37-55; Ad de Bruijne, 'Homosexuality and Moral Authority. A Theological Interpretation of Changing Views in Evangelical Circles', in; Miranda Klaver e.a. (red.), Evangelicals and Sources of Authority, Amsterdam 2016; De Bruijne, Cultuurstrijd, 274v.

21 Marc Angenent, 'Seks voor christenen', Trouw 15-10-2015; 'God in de lage landen', Evangelische Omroep 20-09-2014; Frank G. Bosman, God houdt van seks. Kleine theologie van de erotiek, Utrecht 2015, 44-56; Martin Kamp, Het goddelijk perspectief van het onvolkomen genot. Een onderzoek naar de theologisch betekenis van seksueel genot (Masterthesis Theologische Universiteit), Kampen 2019.

22 Gary Chapman, De vijf talen van de liefde (20 druk), Heerenveen 2014, 92.

23 Everard J. de Jong, En God zag dat het heel goed was. De heiligheid van seksualiteit, Amsterdam 2006, 13, 59, 76.

24 Boersema, Droom, 100. 
de. ${ }^{25}$ Hoewel de vaak aangevoerde bijbelse onderbouwing daarvan vanuit verschillende Griekse woorden onhoudbaar is, ${ }^{26}$ blijft het zinvol de eigen kleur van liefde in verschillende intermenselijke relaties te onderscheiden. De Knijff onderscheidt daarbij naast liefde als 'eros' een 'sexus'. Deze gaat aan eros vooraf en herinnert aan de verwantschap tussen mens en dier. Beide delen fysieke vereniging en voortplantingsdrift. De Knijff plaatst deze 'sexus' in de context van een dualiteit tussen natuur en geest. Zonder de leiband van de geest, worden driften onbeheerst en schaden zij de menselijkheid. Ook Burggraeve wijst op het totaliserende en egocentrische karakter van seksualiteit die de vrije teugel krijgt. De sexus moet worden ingebed in hogere liefdesdimensies: eros, familieliefde, vriendschap en huwelijk. Het huwelijk als verbond voor het leven verenigt alle en biedt de structuur die de 'sexus' menselijk houdt. Bavinck's augustiniaanse visie op liefde kan dit model versterken. Volgens het bijbelse dubbelgebod bestaat er maar één liefde. Deze gaat van God uit naar mensen en doet mensen op hun beurt God en anderen liefhebben. Wanneer mensen God liefhebben, wil deze liefde ook gaan via de naaste en het door God geschapene en wanneer mensen van andere instanties houden mag dit alleen maar om en in God het geval zijn. ${ }^{27}$ Deze ene liefde omvat alle soorten van liefden maar kan in uiteenlopende contexten verschillende nuances vertonen.

Zowel libertinistische als romantische seksualiteit negeert dat seksualiteit zonder kader een onbeheerste destructieve dierlijke drift wordt. Daarvan spreken de schaduwzijden van de seksuele revolutie. Niet voor niets verdween de naïeve openheid voor incest en pedoseksualiteit, klinkt toenemend protest tegen de vrouwonvriendelijkheid van gelegaliseerde prostitutie en betreffen onthullingen van seksueel misbruik steeds meer samenlevingsverbanden. Misschien was Augustinus' veelgesmade zuinige kijk op seksualiteit toch niet zo vreemd. Zelfs het royale bijbelboek Hooglied bevat dubbelzinnige typeringen als 'vuurgloed des Heren' en 'sterker dan de dood'. ${ }^{28}$ Wie seksualiteit romantiserend of moreel neutraal benadert, speelt met vuur.

25 H.W. de Knijff, Venus aan de leiband. Europa's erotische cultuur en christelijke sexuele ethiek, Kampen 1987, 283, 303; zie ook Roger Burggraeve, Zin-volle seksualiteit. Een integraal-relationele benadering in gelovig perspectief. 1. Antropologische en bijbels-theologische horizon, Leuven 1985), 24, 37, 107; Ilse Cornu, Seksuele ethiek in dynamisch en kwalitatief perspectief, Antwerpen 2013.

26 Oliver O'Donovan, The Problem of Self-Love in St. Augustine, Eugene 2006, 10v.

27 Herman Bavinck, Gereformeerde ethiek, Utrecht 2019, 80, 96, 174, 390.

28 H. de Jong, Van oud naar nieuw. De ontwikkelingsgang van het Oude naar het Nieuwe Testament, Kampen 2002, 350-376. 
De keerzijde van De Knijff's onderscheid tussen sexus en eros is dat eros ook los van sexus kan bestaan. In onze cultuur wordt het erotische geseksualiseerd. Maar erotiek betreft de dialectiek van schoonheid en aantrekking, en van hartstochtelijk verlangen en vervulde verbondenheid die niet persé seksueel zijn. Dat blijkt uit de laatmiddeleeuwse spiritualiteit die het verlangen naar God en de eenheid met Christus verwoordde in erotische concepten. ${ }^{29}$ Aan het eind van de twintigste eeuw hernam Rowan Williams deze traditie in een baanbrekend essay. ${ }^{30}$ Gods triniteit is bron van erotische liefde. Tussen Vader, Zoon en Geest bestaat de oorspronkelijke beweging van aantrekking, verlangen en eenheid. Daaraan ontspringt ook menselijke erotiek. Volgens Williams 'verlangt God naar ons alsof wij God zijn'. Zo legt Hij in mensen een verlangen naar de vereniging met Hemzelf en met Christus. Na Williams' essay werkten meerderen deze benadering uit. ${ }^{31}$ De oudtestamentische huwelijksmetafoor voor Gods verbond en de nieuwtestamentische bruiloftsmetafoor voor de eenheid met Christus bieden steun voor deze benadering. Datzelfde geldt voor het boek Hooglied. Zelfs auteurs met een literair-historische benadering concluderen uit de tekstuele ambivalenties dat de erotiek van Hooglied verankering in een fundamentelere eros behoeft. Bovendien verdient ook een geestelijke lezing overweging, die volgens sommigen de reden is geweest om Hooglied in de canon op te nemen. ${ }^{32}$

In de huidige bedeling blijft eros veelal verweven met de sexus. Dat moet echter niet als vanzelfsprekend aanvaard worden. Het kan een ongeordendheid zijn die beheersing vergt. Dan ontvangt eros ook ruimte in niet-seksuele contexten. Omgekeerd richt eros de sexus. Deze is biologisch verbonden met voortplanting. Opwinding en orgasme bevorderen de verbinding van zaaden eicellen. ${ }^{33}$ Tegelijk versterkt het gevoel van genot en geluk de relationele

29 A. de Reuver, Verborgen Omgang. Sporen Van spiritualiteit in Middeleeuwen en Nadere Reformatie, Zoetermeer 2002, 40-46.

30 Rowan Williams, 'The Body's Grace', 1989 (https://www.anglican.ca/wp-content/uploads/ 2010/10/the-bodys-grace.pdf - geraadpleegd 10-01-2017).

31 J.B. Nelson e.a. (red.), Sexuality and the Sacrred. Sources for Theological Reflection, Louisville 1994; Eugene Rogers, Sexuality and the Christian body. Their way into the triune God, Oxford 1999; Sarah Coakley, God, Sexuality, and the Self. An Essay 'On the Trinity', New York 2013; Stuart, Theological, 18-31.

32 De Jong, Oud, 370; D.M. Carr, The Erotic Word. Sexuality, Spirituality, and the Bible, Oxford 2003, 141, 194; Richard M. Davidson, Flame of YAHWEH. Sexuality in the Old Testament, Peabody 2008; Th.C. Vriezen e.a., Oudisraëlitische en vroegjoodse literatuur (10 druk), Kampen 2000, 358.

33 'Wat is het nut van het vrouwelijk orgasme?', De Volkskrant 01-08-2016. 
eenheid. ${ }^{34}$ Toch blijft seksueel genot vluchtig en vaak 'rommelig' en onbevredigend, omringd door disharmonie, teleurstelling, pijn en onvoldaanheid. Orgasmen vormen niet de hemel op aarde. ${ }^{35}$ Dit vluchtige karakter doet mensen steeds weer zoeken naar de verbinding van sexus en eros zonder definitief voldoening te vinden.

Williams stelt de intrigerende vraag waarom God de vrouw een clitoris gaf. Deze heeft volgens de meeste biologen geen functie bij voortplanting. Jongens en meisjes bezitten hetzelfde basisweefsel dat zich alleen bij jongens ontwikkelt tot een penis. De clitoris behoudt echter wel een vergelijkbare gevoeligheid en moet dus alleen bedoeld zijn voor seksueel genot. Williams beschouwt genot daarom als zelfstandig doel van seksualiteit dat niet afhangt van voortplanting. Door de verbinding tussen sexus en eros vertelt de Schepper ons dat Hij ons maakte voor vreugde en geluk. De vluchtigheid van seksueel genot wijst vooruit naar blijvend eschatologisch geluk. Dat blijft voluit erotisch maar de sexus speelt daarbij geen rol meer. Williams' denklijn is aantrekkelijk maar zijn ontkoppeling van genot en voortplanting overtuigt niet. De Bijbel tekent ook kinderen als concretisering van Gods zegen en huwelijksgeluk. Het ligt meer voor de hand het genot van seksueel-erotische eenheid én de kinderzegen samen te beschouwen als heenwijzend naar onvergankelijk eschatologisch geluk.

Het voorgaande brengt mij tot een beperkte omschrijving van seksualiteit die zich concentreert rond de sexus. Seksualiteit betreft de geslachtsdrift tussen man en vrouw en dient Gods belofte van erotisch genot en geluk. Zij betreft alles wat inherent samenhangt met deze geslachtsdrift en de geslachtsgemeenschap waarnaar zij tendeert.

\section{Bijbels-theologisch kader}

Deze beperkte opvatting van 'seksualiteit' helpt om het onderwijs van de Schrift te verwerken. Veelbesproken passages (Leviticus 18 en 20, Romeinen 1, 1 Korinthe 6, 1 Thessalonicenzen 4) betreffen alle deze geslachtsdrift in een engere zin. Door deze in te bedden in het huwelijksverbond verbindt ook de Schrift ze aan andere dimensies van mens-zijn. Buiten dat kader geldt zij als porneia die categorisch wordt afgewezen. ${ }^{36}$ Dat neemt niet weg dat de dialectiek van aantrekking, verlangen en verbondenheid ook in andere relaties bestaat, zoals tussen Ruth en Naomi, David en Jonathan, en Jezus en Johannes.

34 Larry Young e.a., Chemie van de liefde, Utrecht 2013.

35 Stuart, Theological, 29.

36 William R.G. Loader, The New Testament on Sexuality, Grand Rapids 2012, 142, 168v. 
Over deze seksualiteit spreekt de Schrift hooggestemd (Hooglied) én nuchter. In 1 Korinthe 7 lijkt zij voor Paulus vooral een lichamelijke behoefte of drift die ordening behoeft om niet schadelijk te worden. Bovendien maken de fysieke dimensies ervan (zaadlozing, menstruatie) een mens onrein voor God, temeer waar ze buiten de gepaste ordeningen voorkomen (zoals bij overspel of incest). Die ordening lijkt zwaarder te wegen dan het fysieke als zodanig. Bij seksuele omgang van een getrouwde man met een ongetrouwde vrouw is de enige sanctie dat hij haar de rechtsbescherming van een onontbindbaar huwelijk moet bieden (Deuteronomium 22:28). Is ze echter getrouwd, dan volgt de doodstraf, kennelijk niet vanwege het seksuele maar omdat hij de rechten van haar echtgenoot aantast. Slaapt een ongetrouwde vrouw die nog thuis woont met een ander, dan is haar straf zwaarder. Zij schaadt de eer van haar vader (Deuteronomium 22:21). Deze nadruk op de samenlevingsorde spreekt ook uit 1 Korinthe 5. Seksuele omgang met de vrouw van iemands vader heet daar extreem schandelijk. Volgens Loader betreft het hier een stiefmoeder en is de vader zelf al gestorven, wat in een hedendaagse context niet dezelfde verontwaardiging oproept. ${ }^{37}$ Deze nuchtere, weinig hoogdravende én weinig geladen omgang met de sexus is van belang voor vandaag. Zij vormt een medicijn tegen de gebruikelijke moralisering of romantisering ervan onder christenen.

De Schrift verbindt de sexus exclusief aan de schepping van en het huwelijk tussen man en vrouw. Geslachtsdrift, eenheid en voortplanting zijn met elkaar verweven. Daarbij ligt het hoofdaccent niet op voortplanting (zoals vaak gesteld) maar op eenheid. Dat blijkt in 1 Korinthe 7 waar Paulus voortplanting ongenoemd laat, en volgt al uit Genesis 2 waar de zin van de geslachtelijke differentiatie ligt in de mogelijkheid één vlees te worden. Die uitdrukking 'één vlees' betreft een omvattende levenseenheid, maar zinspeelt nadrukkelijk op de geslachtelijke vereniging van twee lichamen die daarvan een uiting is en daaraan bijdraagt. De verhaallijn van Genesis 2 suggereert een verbinding met de verwantschap in oorsprong. Omdat de vrouw uit de man is genomen, is tussen hen een unieke eenheid mogelijk, een her-eniging. Jezus onderstreept dat in Mattheüs 19 door man en vrouw 'niet meer twee' te noemen.

Ook Paulus' verwerking van Genesis 2 in 1 Korinthe 6 verbindt fysieke eenwording met een diepere werkelijkheid. Geslachtsgemeenschap met een prostituee maakt iemand één lichaam met haar. Alleen deze zonde raakt vol-

37 William R.G. Loader, 'Marriage and Sexual Relations in the New Testament World', in: Thatcher, Handbook, 190-205, 193. 
gens hem ons lichaam. Dat duidt op iets bijzonders, aangezien ook drankmisbruik of vraatzucht het lichaam betreffen. Maar alleen seksuele zonde verandert de status van het lichaam principieel, omdat zij daadwerkelijke vereniging met een ander markeert. Dit accent op eenheid ontvangt een eschatologische verdieping. Eenwording met een prostituee strijdt voor alles met de vervulling van de huwelijkseenheid in de liefdesrelatie van christenen met Christus. Paulus noemt niet de breuk in de eenheid met eventuele echtgenotes. Deze nieuwe door de Geest bewerkte lichaamseenheid met Christus vormt een nog groter wonder dan de vereniging van man en vrouw. De onreinheid van seksuele eenwording buiten het huwelijkskader, die des te meer bestaat wanneer de seksuele partner zelf onrein is (zoals een prostituee), raakt primair Christus. Omdat zijn bruid rein moet zijn voor Hem (2 Korinthe 11:2), maakt onreinheid haar onwaardig tot deze nieuwe lichaamseenheid.

Deze christologisch-eschatologische oriëntatie, die de scheppingswerkelijkheid vervult en transformeert, vormt de kern van de nieuwtestamentische ethiek. In de traditionele protestantse ethiek bleef zij zwak, zeker rond huwelijk en seksualiteit. Uit reactie op Rome en het anabaptisme oriënteerde de protestantse huwelijksethiek zich eenzijdig op de scheppingsorde van het begin. ${ }^{38}$ Een meer eschatologische benadering geeft oog voor toekomstige structurele veranderingen rond de seksualiteit. Voortplanting heeft eens afgedaan en ontvangt daarom al in het Nieuwe Testament nauwelijks nadruk. In Lukas 20:36 staat dat mensen in het eschaton niet meer trouwen omdat zij niet meer sterven. Kennelijk stond voortplanting ook toen al meer in verbinding met de noodzaak van nieuwe generaties binnen een sterfelijke mensheid dan met de opdracht uit Genesis 1 . Het wegvallen van voortplanting impliceert ingrijpende lichamelijk veranderingen, bijvoorbeeld voor geslachtsorganen en geslachtsdrift. Volgens 1 Korinthe 15 is het opstandingslichaam inderdaad geestelijk en hemels in plaats van natuurlijk en aards. Zoals God de buik teniet doet omdat onsterfelijke mensen niet meer afhankelijk zijn van voedsel, zo transformeert hij ook de sexus en de lichaamsstructuur van mannen en vrouwen. Ook Paulus' allusie op Genesis 1 in Galaten 3:28 suggereert dat het 'mannelijk en vrouwelijk' in Christus geen rol meer speelt. Ook wie niet met veel vroege kerkvaders (vaak met vrouwonvriendelijke ondertonen) uitgaat van een androgyne toekomst, moet verrekenen dat de eenheid in Christus fundamenteler wordt dan de tweeheid van man en vrouw. ${ }^{39}$ Volgens Jezus

38 Brent Waters, The Family in Christian Social and Political Thought. Oxford 2007, 28, 132v., 138.

39 Peter Brown, The Body and Society. Men, Women and Sexual Renunciation in Early Christianity, New York 2008, 112-114. 
zullen mensen zijn als engelen. De lichamelijke verwantschap met de dieren in de oude schepping verandert in het eschaton in een fysieke affiniteit met de engelen.

Deze transformatie van seksualiteit in iets waarvoor geslachtelijkheid niet meer bepalend is, zou ook de exclusiviteit van de huwelijkseenheid tussen man en vrouw kunnen relativeren. Toch versterkt de christologisch-eschatologische invalshoek deze juist. In Efeze 5 verbindt Paulus haar op een nieuwe manier met de eschatologische eenheid met Christus, volgens de meeste handschriften door Adams lied op Eva expliciet te citeren. Seksueel één-vlees-worden in een christelijk huwelijk markeert het één-lichaam-zijn met Christus. Vlak voor de definitieve vervulling van het huwelijk ontvangt het tijdelijk nog een extra verwijzende taak voor Christus' koninkrijk. Daarom luistert het in het Nieuwe Testament juist nauwer dan ooit met de exclusiviteit van de huwelijksliefde, de onontbindbaarheid van het huwelijksverbond en de ordening van de sexus binnen de unieke eenheid tussen man en vrouw. ${ }^{40}$

\section{Praktisch-ethische implicaties}

Een christologisch-eschatologische invalshoek heeft praktisch-ethische implicaties. Deze verdienen verwerking in opvoeding, prediking, catechese, vorming, en ethisch pastoraat. Alleen zo groeit misschien een christelijke seksuele ethiek die de seksuele revolutie voorbijkomt. Zonder deze vorming mist de christelijke omgang met urgente seksueel-ethische thema's overtuigingskracht.

\section{a. Twee basisvoorwaarden}

Uit het voorgaande volgen twee basisvoorwaarden voor een seksuele ethiek vandaag. In de eerste plaats vergt de 'erotische' bruidsrelatie tot Christus inoefening. Deze biedt tegenover de laatmoderne seksualiteitsbeleving een nieuw uitgangspunt voor christelijk zijn, denken en handelen. Hoe sterker de voldoening in Christus, des te duidelijker wordt het voorlopige van seksueel geluk en genot. En hoe overtuigender de voorproeven van deze nieuwe 'erotiek' in christelijke verbondenheid tussen vrienden, familieleden en medechristenen, des te relatiever de dynamiek van de seksuele drift. Zonder een doorleefde bruidsrelatie tot Christus is de kerk in een laatmoderne context te zwak om sexus en driftleven te beheersen en te richten op Gods doelen. Zij is belangrijk in relaties waarin de sexus (nog) geen rol zou moeten spelen,

40 A.J. Köstenberger, 'The Mystery of Christ and the Church: Head and Body, One Flesh', Trinity Journal 12(1991), 1, 79-94. 
maar bijvoorbeeld ook in de omgang met porno (al verdienen daarbij evengoed psychologische en neurobiologische aspecten aandacht). ${ }^{41}$

In de tweede plaats lijkt herontdekking van de christelijke vreemdelingschap in de omgang met invloeden uit de omringende cultuur noodzakelijk. Met name oude en nieuwe media, die de beeldvorming rond seksualiteit sterker blijken te beïnvloeden dan christelijke onderlinge vorming, verdienen een ascetischer gebruik. Dit lijkt wellicht een onrealistisch voorstel in een christenheid die op dit punt al heeft toegegeven, maar het is nooit te laat om opnieuw te beginnen, bijvoorbeeld bij de opvoeding van nieuwe generaties vanaf nu.

\section{b. Celibaat als voorkeursoptie}

Een christologisch-eschatologische insteek betekent het opnieuw serieus nemen van de vroegchristelijke voorkeur voor ongehuwd-zijn en celibaat. Vanuit schepping en Oude Testament vormen beide hoogstens uitzonderingen, die gebrokenheid en lijden markeren. In de eschatologische context van 1 Korinthe 7 geeft Paulus er echter onder voorwaarden de voorkeur aan. Ook wie niet één vlees is met een partner, deelt al in de beginnende werkelijkheid van Christus' lichaam. Dit celibaat mag niet op grond van Paulus' typering 'gave' worden beperkt tot wie geen (sterke) seksuele behoeften bezitten. Onderzoek onder bewust-celibatairen leert dat ook zij meestal seksuele driften en verlangens kennen. ${ }^{42}$ Het gaat om de geloofskeus om door genade de sexus bewust te schikken onder de dienst aan Gods koninkrijk. Op dezelfde wijze spreekt Jezus in Mattheüs 19 over mensen 'aan wie het gegeven is' dat zij 'zichzelf gesneden hebben ter wille van het koninkrijk'. Ondanks de vrijwilligheid kan zo'n keuze pijnlijk zijn. Dezelfde toonsoort klinkt in Jezus' woorden over vrijwillig prijsgeven van relaties en bezit, opnemen van het kruis en zichzelf verloochenen.

\section{c. Beheersing van de sexus}

De christologisch-eschatologische oriëntatie biedt nieuwe grond onder de altijd al nodige beheersing van de sexus. Juist na de seksuele revolutie moeten christenen niet eenzijdig het mooie van seksualiteit benadrukken, maar ook de totaliserende en destructieve dimensie ervan concreet aanwijzen. Beheersing is niet minder belangrijk dan dankbaar gebruik. Dat de sexus op verdwij-

41 William M. Struthers, Wired for Intimacy. How pornography hijacks the male brain, Downers Grove 2009, 11-18, 83-114, 155-176.

42 Gareth Terry, "'I'm Putting a Lid on that Desire". Celibacy, Choice and Control', Sexualities 15 (2012), $7,871-889$. 
nen staat, motiveert daartoe extra. De hedendaagse tendens tot ongebreideld gebruik moet plaatsmaken voor een ordening naar de doelen die zij tijdelijk nog dient. Sommige exegeten menen dat Paulus in 1 Thessalonicenzen 4:4 zelfs expliciet benoemt dat het mannelijk geslachtsorgaan deze controle behoeft. ${ }^{43}$

Wat Paulus in 1 Korinthe 7 schrijft over de algehele omgang met het resterende aardse leven, geldt ook de sexus. Zoals christenen bezitten als niet bezittend en getrouwd-zijn als niet getrouwd, zo gebruiken zij de sexus als waren zij celibatair. De Heidelbergse Catechismus (antwoord 108) gebruikt de term 'kuisheid' als van toepassing buiten en binnen het huwelijk. Dat impliceert principiële overeenkomst tussen gehuwden en ongehuwden. Alleen als christenen dit weer samen leren, ontstaat een overtuigende bedding voor wie geen of nog geen seksuele relatie kunnen hebben: homo's, hetero's zonder verkering, hartsvrienden, en verkerenden die de 'hogere' relationele dimensies nog moeten ontwikkelen of nog niet toe zijn aan een levenslang verbond. Ook binnen het huwelijk hoort 'Venus aan de leiband' en moeten 'hogere' relationele dimensies belangrijker zijn dan de sexus. Hoewel nog intrinsiek en voluit deel van de voorbijgaande maar legitieme en beloftevolle ordening van het huwelijk, is seksualiteit principieel een concessie geworden aan een wereld die voorbijgaat. ${ }^{44}$ Dat verdient in huwelijken tot uiting te komen door een bewust ritme van afgesproken perioden van onthouding die spiritueel gekleurd zijn. Het helpt ook getrouwden voor wie seksuele omgang lastig of onmogelijk werd.

Tegelijk mogen wij niet idealistisch de ogen sluiten voor de laatmoderne realiteit. Zelfs wanneer wij bovengenoemde richting inslaan, zet de totaliserende trek van de sexus ook christenen onder druk. Tegen dat decor neig ik bijvoorbeeld tot een genuanceerder oordeel over masturbatie dan in het verleden veelal gebruikelijk. Die vroegere zware morele lading had ook te maken met de focus op het seksuele als zodanig, waarvan ik vaststelde dat de Bijbel deze zo niet kent. Bij masturbatie worden juist geen samenlevingsordeningen doorbroken. Wel zijn - zeker in het internettijdperk - overspelige beelden en fantasieën dichtbij, maar dan is pornografie het probleem en niet masturbatie zelf. Voor velen vormt zelfbevrediging het enige alternatief voor verdergaande ongeordendheid. ${ }^{45}$ Daarom verdient het overweging om masturbatie positiever te benaderen als minstens een zekere beheersing van de sexus. In plaats

43 Jay E. Smith, ' 1 Tessalonians 4,4. Breaking the Impasse', in: Bulletin for Biblical Research 11(2001), 1, 65-105.

44 Stuart, Theological, 28.

45 Douma, Seksualiteit, 86-90. 
van het gebruikelijke zwijgen erover zou juist openlijk besproken moeten worden hoe seksuele spanning zich via masturbatie kan oplossen zonder overspelige of pornografische fantasieën.

\section{d. Hoopvol perspectief}

Een christologisch-eschatologisch perspectief biedt hoop bij verstoringen rond de sexus. Dat leert Jezus' woord over eunuchen in Mattheüs 19. Zij moesten in Israël afstand houden van het heiligdom, maar zijn welkom bij Christus (Handelingen 8) en staan zelfs model voor vrijwillige christelijke zelfverloochening. Wie noodgedwongen afziet van de sexus, mist niet alleen iets maar wordt tegelijk voorloper naar de eschatologische lichamelijkheid. Dit inzicht doet anders omgaan met gendervarianten en seksuele oriëntaties die niet passen bij de geschapen man-vrouwpolariteit, bijvoorbeeld die van homo's, lesbiennes, biseksuelen, pedoseksuelen, interseksuelen en transgenders. ${ }^{46}$ De kerk moet afleren om hen primair te beschouwen als mensen die lijden onder gebrokenheid. Zij blijken juist evengoed als anderen onderweg naar het nieuwe mens-zijn in Christus, waarbij elke oriëntatie op een nieuwe manier kan meekomen en vruchtbaar worden. Dit werpt bijvoorbeeld ander licht op geslacht veranderende operaties. Wanneer je man- of vrouw-zijn (met welke seksuele voorkeur ook) niet langer je identiteit bepaalt, wordt het de vraag waarom je jezelf persé exclusief met één van beide en de bijpassende genderparadigma's zou moeten identificeren en eventueel laten opereren. Tegelijk verdwijnt de zware morele lading wanneer onder de druk van heersende genderparadigma's in samenleving én kerk een kosmetische operatie voelt als enige uitweg. Met een variatie op Paulus (Galaten 6:15) kunnen we misschien zeggen: wel of niet opereren maakt niet uit, maar of men een nieuwe schepping is.

\section{e. Binnen de gegeven structuren}

Een christologisch-eschatologisch perspectief moet de gegeven structuren van deze wereld respecteren en niet revolutionair doorbreken. Dat deden ooit de anabaptisten en het herhaalt zich vandaag wanneer 'Queer'-theologen polyamoreus gedrag eschatologisch rechtvaardigen. ${ }^{47}$ Juist omdat de christelijke levensstijl anticipeert op Gods toekomst benadrukken de apostelen dat

46 Megan K. DeFranza, Sex Difference in Christian Theology: Male, Female, and Intersex in the Image of God, Grand Rapids 2015, 285-289.

47 Robert E. Goss, 'Proleptic Sexual Love. God's Promiscuity Reflected in Christian Polyamory', Theology \& Sexuality 11 (2004), 1, 52-63; Kevin Garcia, Is Jesus cool with polyamory?' (https://www.youtube.com/watch?v=ZNIWjShfHc0 - geraadpleegd 20-09-2019). 
christenen zich daarmee desondanks waar mogelijk moeten voegen in de gegeven samenlevingsstructuren. ${ }^{48}$ Dat zijn echter geen onveranderlijke scheppingsstructuren. Daarvan biedt de Bijbel nauwelijks concretiseringen en ook vanuit de natuur volgen vandaag minder evident dan vroeger algemeen gedeelde conclusies. In gegeven structuren is iets van de oorspronkelijke schepping én iets van Gods geduldige bewaring van de gevallen schepping op weg naar Christus' toekomst. Beide zijn vaak niet eenduidig te onderscheiden en vertonen per context verschuivingen die onder Gods voorzienigheid aanvaard kunnen worden. ${ }^{49}$

Dit inzicht biedt een kader voor allerlei praktijkvragen, bijvoorbeeld rond de toename van samenwonen onder christenen. Het is te sterk om te stellen dat het sluiten van een burgerlijk huwelijk voor twee christenen die zich aan elkaar verbinden een goddelijke roeping is. Het burgerlijk huwelijk is een contingente historische ordening die zich inmiddels steeds verder verwijdert van bijbelse noties. Daarnaast ontstonden andere publieke ordeningsinstrumenten, terwijl een postchristelijke samenleving de kerk uitdaagt om aanvullende eigen vormen te ontwikkelen. Bovendien zijn ook christelijke jongeren geïndividualiseerd en beginnen zij hun relaties anders dan in de vroegere collectieve samenlevingsorden. De toename van ongeordende seksualiteit en vrijblijvend samenwonen tijdens de verkeringstijd kan waarschijnlijk doeltreffender worden tegengegaan wanneer de kerk hierop inspeelt en creatief wegen vindt die passen bij de veranderde context dan wanneer zij contingente vormen van vroeger verabsoluteert. ${ }^{50}$ Tegelijk is de kerk nog niet zover, zodat de rommelige praktijk van voorhuwelijkse seks, ongeordend samenwonen, samenwonen als eerste stap naar een huwelijk en opteren voor alternatieve publieke vormen in plaats van het burgerlijk huwelijk, vooralsnog voortduurt. Zonder het bijbels onderwijs te verzwakken, kan de kerk dit rommelige proces beter geduldig begeleiden dan dwingend sturen. Dit geldt temeer tegen de achtergrond van het eerdergenoemde seksueel moratorium van westerse jongeren. ${ }^{51}$

48 Bruce W. Winter, Seek the Welfare of the City. Christians As Benefactors and Citizens. FirstCentury Christians in the Graeco-Roman World, Grand Rapids 1994, 15-24.

49 Bavinck, Ethiek, 120.

50 Deputaten RKO/H\&E, Aanvullende beloften gevraagd! Kerkelijke omgang met de verschillende wettelijke mogelijkheden voor relatievorming (Bijlage Huwelijk en samenlevingsvormen rapportage Generale Synode Gereformeerde Kerken vrijgemaakt Ede 2014 - https://www. gkv.nl/organisatie/generale-synode/beleidsrapporten-gs-2014/ - geraadpleegd 05-09-2019).

51 Adrian Thatcher, Marriage After Modernity. Christian Marriage in Postmodern Times, Sheffield 1999, 103-131. 


\section{f. Sexus en erotiek buiten het huwelijk?}

Op grond van een christologisch-eschatologische benadering bepleit de Britse ethicus Song ruimte voor de sexus in andere verbondsrelaties dan die van het man-vrouwhuwelijk. Omdat een getransformeerde werkelijkheid nadert waarvoor geslachtelijke dualiteit niet meer doorslaggevend is, kunnen seksuele eenwording en geluk ook aan anderen gegund worden, bijvoorbeeld homo's. ${ }^{52}$

Deze redenering is plausibel en verdient overweging. Op dezelfde wijze kunnen gehuwden met recht afzien van kinderen omdat zij samen op een nieuwe wijze vruchtbaar en gelukkig willen zijn voor Gods koninkrijk. Toch vormt mijn bovengenoemde conclusie dat de sexus in deze 'laatste dagen' zelfs nadrukkelijker dan eerder de unieke man-vrouweenheid dient, een voor mij doorslaggevend tegenargument. Tegelijk besef ik dat sommigen die gedachte te sacramenteel-katholiek vinden en anders kunnen afwegen. Bovendien is het voor christenhomo's minstens zo moeilijk als voor hetero's om tegenover de druk van de seksuele revolutie een alternatief beeld van seksualiteit te ontwikkelen en te doorleven. Daarom moeten de kerken minstens de vraag overwegen of zij hierop niet toch moeten inspelen en deze manifestatie van de sexus buiten het kader van het huwelijk beter kunnen ordenen dan ongebonden laten. Vooraanstaande ethici als Hauerwas en O'Donovan, die beiden homoseksuele relaties in beginsel afwijzen, overwegen toch elk de mogelijkheid van een ordening voor homorelaties. Deze zou nadrukkelijk geen huwelijk zijn maar analoog aan het huwelijk wel de wijsheid ervan willen benutten. Dat vormt dan niet de ultiem-goede stap naar het komende koninkrijk voor alle contexten maar gegeven de marges van de huidige samenlevingsorde misschien wel de best-mogelijke voor sommige homo's. ${ }^{53}$

Belangrijker dan ruimte zoeken voor de sexus buiten het huwelijk is echter een christologisch-eschatologische ontwikkeling van de andere dimensies van liefde in christelijke relaties. Ruimte creëren voor eros zonder automatisch ook een rol voor de sexus biedt tegengif tegen de imperialistische laatmoderne 'seksualiteit'. De christelijke gemeente zou naast bestaande levensordeningen als huwelijk en natuurlijke familie vanuit de gedeelde liefde voor God nieuwe vormen van verbondenheid en samenleven moeten ontwikkelen. De gemeente zelf vormt daarvan de primaire uiting. De Bijbel typeert deze niet-

52 Robert Song, Covenant and Calling. Towards a Theology of Same-Sex Relationships, Londen 2014, hoofdstuk 3.

53 Oliver O'Donovan, 'The Wreck of Catholic Identity. Marriage Canon Revision in the Scottish Episcopal Church', Fulcrum 14-05-2016 (https://www.fulcrum-anglican.org.uk/ articles/the-wreck-of-catholic-identity-marriage-canon-revision-in-the-scottish-episcopal-church/); Hauerwas, Hope, 49. 
natuurlijke verbondenheid met termen voor bestaande aardse ordeningen, die nieuwe inhoud krijgen. Christenen vormen 'families' van broers en zussen, 'vriendenkringen', politieke 'vergaderingen' (ekklesia), en een veelzijdig begaafd 'lichaam' dat tegelijk een 'bruid' is. Deze metaforen roepen om concretiserende vormgeving in geestelijke 'extended family's', huisgemeenten, leefgemeenschappen, vriendengroepen, een op een vriendschappen, verbonden, buddyrelaties en meer. ${ }^{54}$

Binnen zulke verbanden spelen (niet-seksuele) erotische antropologische aantrekking, verlangen en vervulling altijd een rol. Christus' liefde heiligt deze en maakt ze tot voorproef van het komende koninkrijk. Daarin ligt de eschatologische vervulling van Gods woord uit Genesis 2 dat het 'niet goed' is dat de mens alleen blijft. Dit kan ook de laatmoderne categorie van de 'single' reformeren. Daarin klinkt de echo van de bijbelse voorkeur voor ongehuwd-zijn maar werkt vooral westers individualisme door. Wie geen partner heeft, is in onze cultuur vaak wel alleen. De christelijke gemeente kan concreet maken hoe het ook voor mensen zonder seksuele partner niet goed is dat de mens alleen is.

Hier loopt volgens mij ook de koninklijke weg voor christelijke 'lhbt'ers'. Ook zij zouden dan delen in die erotische verbondenheid in Christus, via vriendschappelijke en familiaire relaties als begin van vervuld mens-zijn. Tegelijk zou duidelijk blijven dat de sexus juist in deze 'laatste dagen' verbonden blijft aan de eenheid tussen man en vrouw. Maar opnieuw constateer ik hoe ver dit afstaat van de huidige kerkelijke praktijk, zowel wat betreft de omgang met erotiek en seksualiteit als wat betreft christelijke gemeenschapsvorming. En opnieuw moet dat leiden tot tegemoetkomingen aan betrokkenen. Minstens zou de kerk specifieke partnerschappen moeten aanvaarden tussen homo's en lesbiennes die zich tot elkaar aangetrokken voelen en tegelijk oprecht proberen om in hun relatie wel eros maar niet sexus volle ruimte te geven. Ongetwijfeld wordt dat een zoektocht, met vallen en opstaan en soms rommelige grenzen. Maar binnen de gegeven marges van dit moment lijkt dit voor veel homo's en lesbiennes het enig reële alternatief tussen eenzaamheid en vertwijfeling enerzijds en een voluit seksuele relatie anderzijds. In dat geval vormt het voor hen de best mogelijke stap vooruit naar Gods toekomst.

A.L.Th. de Bruijne is hoogleraar ethiek en spiritualiteit aan de Theologische Universiteit Kampen.

54 Wesley Hill, Spiritual Friendship. Finding Love in the Church as a Celibate Gay Christian, Grand Rapids 2015. 